\title{
Effects of reduced salinities on development and bioenergetics of early larval shore crab, Carcinus maenas
}

\author{
K. Anger ${ }^{\mathrm{a}, *}$, E. Spivak ${ }^{\mathrm{b}}$, T. Luppi ${ }^{\mathrm{b}}$ \\ ${ }^{a}$ Biologische Anstalt Helgoland, Meeresstation, D-27498 Helgoland, Germany \\ ${ }^{\mathrm{b}}$ Facultad de Ciencias Exactas y Naturales, Departamento de Biología, Universidad Nacional de Mar del \\ Plata, C.C. 1245, 7600 Mar del Plata, Argentina
}

Received 13 January 1997; received in revised form 24 March 1997; accepted 10 April 1997

\begin{abstract}
The shore crab, Carcinus maenas L. (Portunidae), is a coastal and estuarine species, which can live and reproduce under brackish water conditions; freshly hatched larvae have been observed in the field at salinities below $15 \%$. In the present laboratory study, the tolerance of hypo-osmotic stress was experimentally investigated in early larvae of a marine (North Sea) population of $C$. maenas reared at four different salinities $(15,20,25,32 \%$ ). Two and 4 days after hatching, the Zoea I larvae were moult-staged microscopically, and their rates of respiration and growth (changes in dry weight, $W$, carbon, $C$, nitrogen, $N$, and hydrogen, $H$ ) were measured. Survival and development were monitored until the megalopa was reached: $15 \%$ o did not allow for development beyond the first zoeal stage, while metamorphosis to the megalopa was reached at salinities $\geq 20 \%$. At $20 \%$, development was significantly delayed and mortality enhanced as compared with 25 and $32 \%$. Rates of growth and respiration decreased during exposure to reduced salinities $\leq 25 \%$. Hence, the suppression of growth could not be explained as a consequence of enhanced metabolic losses per larva. Instead, a partial $C$ budget indicates that the Zoea I larvae suffered from decreased capabilities of assimilating ingested and subsequently converting assimilated matter to tissue growth. Net growth efficiency $\left(K_{2}, C\right.$-based) was at 25 and 32\%o initially high ( $>60 \%$ during the postmoult and intermoult stages of the Zoea I moult cycle), but decreased during the later stages (down to $\leq 30 \%$ in premoult). An inverse pattern of $C$ partitioning was observed at $\leq 20 \%$, with initially low $K_{2}$ values ( $\leq 21 \%$ during the first 2 days of the moult cycle), and a later increase (up to $\geq 46 \%$ in premoult). Thus, larval growth was initially suppressed under conditions of reduced salinity, but this was later (during premoult) partially compensated for by an increase in $C$ assimilation and $K_{2}$. Our observations indicate that Zoea I shore crab larvae react during the late stages of their moulting cycle less sensitively against reduced salinities than during postmoult and intermoult. This suggests that the transition between moult cycle stages $\mathrm{C}$ and $\mathrm{D}_{0}$ may be a critical point for effects of hypo-osmotic stress, similarly as already known in relation to effects of nutritional stress. Negative effects were found also when
\end{abstract}

* Corresponding author. 
freshly hatched Zoea I shore crab larvae were exposed only transitorily (for 24-72 h) to 20\%o, with significantly lower rates of survival, development, growth, respiration, and $K_{2}$. These effects increased with increasing duration of initial exposure to reduced salinity. (C) 1998 Elsevier Science B.V.

Keywords: Crab larvae; Salinity tolerance; Larval growth; Larval respiration; Carbon; Nitrogen

\section{Introduction}

The common shore crab, Carcinus maenas L., is widely distributed on both sides of the North Atlantic Ocean, where it is found on a variety of soft and hard substrates, both in the intertidal and subtidal zones (Christiansen, 1969; Williams, 1984). Its life history was reviewed by Broekhuysen (1936), Crothers (1967), (1968), and Berill (1982). C. maenas has been introduced to Australia (Zeidler, 1978), recently also to California, where it seems to spread rapidly (Cohen et al., 1995; Grosholz and Ruiz, 1995). As an opportunistic and very euryhaline species, it is a typical inhabitant not only of coastal environments, but also of brackish inland waters such as the Dutch estuaries (Wolff and Sandee, 1971) and the western Baltic Sea (Poulsen, 1922). While adult crabs can live over extended periods in water with down to about $6 \%$ salinity, reproduction, embryogenesis, and larval development of this species require much higher salt concentrations (Green, 1968; Kinne, 1971; Nagaraj, 1993).

The minimum salinity for successful egg development is in general believed to be above 20\%o (Barnes, 1994), according to Broekhuysen (1936) even above 26\%o. Rasmussen (1959) observed that ovigerous females tended to remain in the lower parts of Danish estuaries, which corroborates the hypothesis that hatching of $C$. maenas larvae takes place in waters with relatively high salt concentrations. On the other hand, however, ovigerous females are commonly found in Kiel Fjord, western Baltic Sea, where near-bottom salinities vary between 15 and 26\%o, and freshly hatched larvae are seasonally abundant in the surface plankton at average salinities of about $15 \%$ (range, 9-26\%o; Kändler, 1959, 1961). In recent laboratory experiments, we incubated ovigerous North Sea crabs from Helgoland in water with 20 and 15\%o salinity, and the eggs developed successfully from early embryonic stages to hatching, although with high mortality at $15 \%$ (Seidler and Anger, unpubl. data). Hence, the limits for embryonic development and egg hatching in $C$. maenas are probably lower than generally presumed, and shore crab larvae may hatch in brackish estuaries, where they are likely to be exposed to poly- or mesohaline conditions (cf. Kändler, 1961).

The larval development of $C$. maenas comprises four zoeal stages and a megalopa (Rice and Ingle, 1975), and each of these instars passes through five major stages (A-E) and several substages of the moulting cycle (Anger, 1983; Stevenson, 1985). Dawirs et al. (1986) described changes in daily larval growth rate during development in seawater (ca. 32\%o) at different temperatures. According to this paper, larval development takes, at an average summer temperature of $18^{\circ} \mathrm{C}$, about $4-5$ days in each of the zoeal instars and 12 days in the megalopa. In the present investigation, we studied effects of reduced 
salinities on survival, development, metabolism, and growth in early shore crab larvae from Helgoland, North Sea, reared at constant $18^{\circ} \mathrm{C}$. From this data, a partial carbon budget was derived to detect possible shifts in larval energy partitioning under hypoosmotic stress. A comparative study is planned with $C$. maenas larvae originating from a Baltic Sea population, which lives permanently in brackish water.

\section{Materials and methods}

Female shore crabs (Carcinus maenas) carrying eggs in advanced stages of embryonic development were collected in July and August 1991 and in June 1993 from the rocky intertidal zone of the island of Helgoland (North Sea). They were maintained in flow-through laboratory aquaria at ambient temperatures and salinities (ca. $16-18^{\circ} \mathrm{C}$; $32 \%$ o), until larvae hatched a few days later. In the 1991 experiments, freshly hatched larvae were transferred to four different test salinities $(15,20,25$, and 32\%o), where their survival and development was monitored during all four zoeal stages. The transference to $25 \%$ o was direct, that to lower salinities allowed for an acclimation in steps of $5 \%$ and $3 \mathrm{~h}$ intervals. Foskett (1977) and Charmantier and Charmantier-Daures (1991) had shown that an acclimation time of $1-2 \mathrm{~h}$ is sufficient for decapod larvae to reach a constant haemolymph concentration. Reduced salinities were obtained by dilution of $1-\mu \mathrm{m}$ filtered sea water (32\%o) with desalinated water. Salinities were checked with a hand refractometer (Krüss Salinometer S-28) to the nearest $1 \%$.

In this series of experiments, each treatment was initiated with 100 individuals. The larvae were reared in 400-ml glass bowls at an initial density of 50 individuals per bowl. During daily water change, the larvae were fed with freshly hatched Artemia sp. nauplii (San Francisco Bay Brand ${ }^{\mathrm{TM}}$, ca. $10 / \mathrm{ml}$ ) and checked for moults or mortality. Freshly moulted individuals were transferred to new marked bowls, so that each rearing vessel contained exclusively larvae with an identical moulting history in each stage (Anger, 1996). In subsequent developmental stages, larval density was reduced stepwise from 50 to 20 per bowl. All experiments were carried out at a constant temperature of $18^{\circ} \mathrm{C}$ and an artificial 12:12 h light:dark cycle.

Additional mass-cultures were maintained for the study of bioenergetics in the Zoea I. Transference to different salinities, water change, and feeding followed the same procedures as described above. Samples were taken from freshly hatched, 2-, and 4-day old larvae, and their dry weight $(W)$, carbon $(C)$, nitrogen $(N)$, and hydrogen $(H)$ contents, as well as respiration rates $(R)$ were measured. $W$ was measured to the nearest $0.1 \mu \mathrm{g}$ on a Mettler UM3 microbalance, elemental composition $(C, N, H)$ with a model 1108 Carlo Erba CHN Analyser, applying standard techniques (Anger et al., 1989). These measurements of larval biomass were made in six replicate samples each, with 50 larvae per replicate analysis.

The determination of metabolic rates $(R)$ was conducted in 60-ml Winkler bottles filled with Millipore-filtered $(0.25 \mu \mathrm{m})$ water with preadjusted salinities (Tables 1 and 2; Anger et al., 1989). For each measurement, eight replicate experiments (with 40 larvae each) and four replicate controls (without animals) were run. Both the experimental and control bottles were incubated for $15 \mathrm{~h}$, before the decrease of oxygen concentration was 
measured with a semiautomatic titration Metrohm Dosimat 665 apparatus. Respiration rates were converted to rates of metabolic carbon loss assuming an average respiratory quotient of 0.9 (conversion factor, $0.3375 \mu \mathrm{g} \mathrm{C} / \mu \mathrm{g} \mathrm{O} \mathrm{O}_{2}$; Anger, 1990).

Another subsample (five larvae) from each treatment was moult-staged microscopically. Integumentary changes were checked in the zoeal telson (for more details see Anger, 1983). In a simplified classification system, moult-cycle stages A-C (postmoult and intermoult) were considered combined, with a gradual increase in the density of epidermal tissues and in the thickness of the cuticle. The onset of the premoult phase (early premoult, substage $\mathrm{D}_{0}$ ) was defined by the beginning of epidermal retraction from the old cuticle (apolysis), intermediate premoult (substage $\mathrm{D}_{1}$ ) by the beginning of epidermal invagination, and late premoult $\left(\mathrm{D}_{2}\right)$ by the appearance of a new cuticle on the epidermal surface. Stage E is identical with the moulting process (ecdysis).

In the second set of experiments (1993), we simulated a transitory initial exposure to reduced salinity after larval hatching in an estuary. These experiments were restricted to the first zoeal stage. Since our 1991 study had shown that an exposure to 20\%o caused significantly reduced growth, but still allowed for successful development through all zoeal stages, this salinity was chosen to measure the effects of transitory hypo-osmotic stress. Freshly hatched Zoea I larvae were distributed among five experimental treatments, with 50 individuals each: A, continuous rearing in sea water (32\%o; control condition); B, exposure to $20 \%$ only during the first day after hatching, then retransferred to sea water; $\mathrm{C}$, initial exposure to $20 \%$ o for 2 days; $\mathrm{D}$, initial exposure to $20 \%$ o for 3 days; E, continuous rearing at $20 \%$ (second control condition; experimental design illustrated in Fig. 4c). From mass cultures (same rearing techniques as above), daily samples of larvae were taken for moult-staging and determinations of $W, C, N, H$ and $R$.

Statistical analysis of mortality, development, growth, and respiration data followed standard methods (Sokal and Rohlf, 1981; Sachs, 1984). As goodness-of-fit $G$-tests showed that our data deviated in some cases from a normal distribution, non-parametric tests were consistently used for their analysis. In contingency tables (mortality data), analysis of multiple data sets as well as pairwise comparisons were carried out with Pearson's log-likelihood test, using a chi-squared statistic. In data sets of development duration, growth, and metabolism, Kruskal-Wallis rank tests ( $H$-tests) were used for multiple comparisons of mean values (non-parametric ANOVA). The Tukey-Kramer HSD ('honestly significant difference') coefficient indicated significantly differing mean values within groups of means; pairwise comparisons were then carried out employing Wilcoxon-Mann-Whitney $U$-tests. Three levels of statistical significance are distinguished in this paper, with probabilities of error: $p<0.05,<0.01$, or $<0.001$ (in graphs indicated by $*, * *$, or $* * *$, respectively).

\section{Results}

\subsection{Continuous exposure to reduced salinities}

At $15 \%$ salinity, the larvae of Carcinus maenas survived for a maximum of 9 days, 
without moulting to the Zoea II stage. Microscopical examination revealed that most larvae died either in the transition between moult cycle stages $\mathrm{C}$ and $\mathrm{D}_{0}$ (intermoultearly premoult), or when they were approaching ecdysis (late premoult, stages $\mathrm{D}_{3-4}$ ). At salinities from 20 to $32 \%$, the larvae showed initially a euryhaline response, with $100 \%$ survival to the second zoeal stage (Fig. 1a). Development duration in the Zoea I stage, however, lasted at $20 \%$ o significantly longer than at higher salinities (Fig. 1b). A delay in moulting occurred at $20 \%$ also in later zoeal stages, accompanied by an increasing
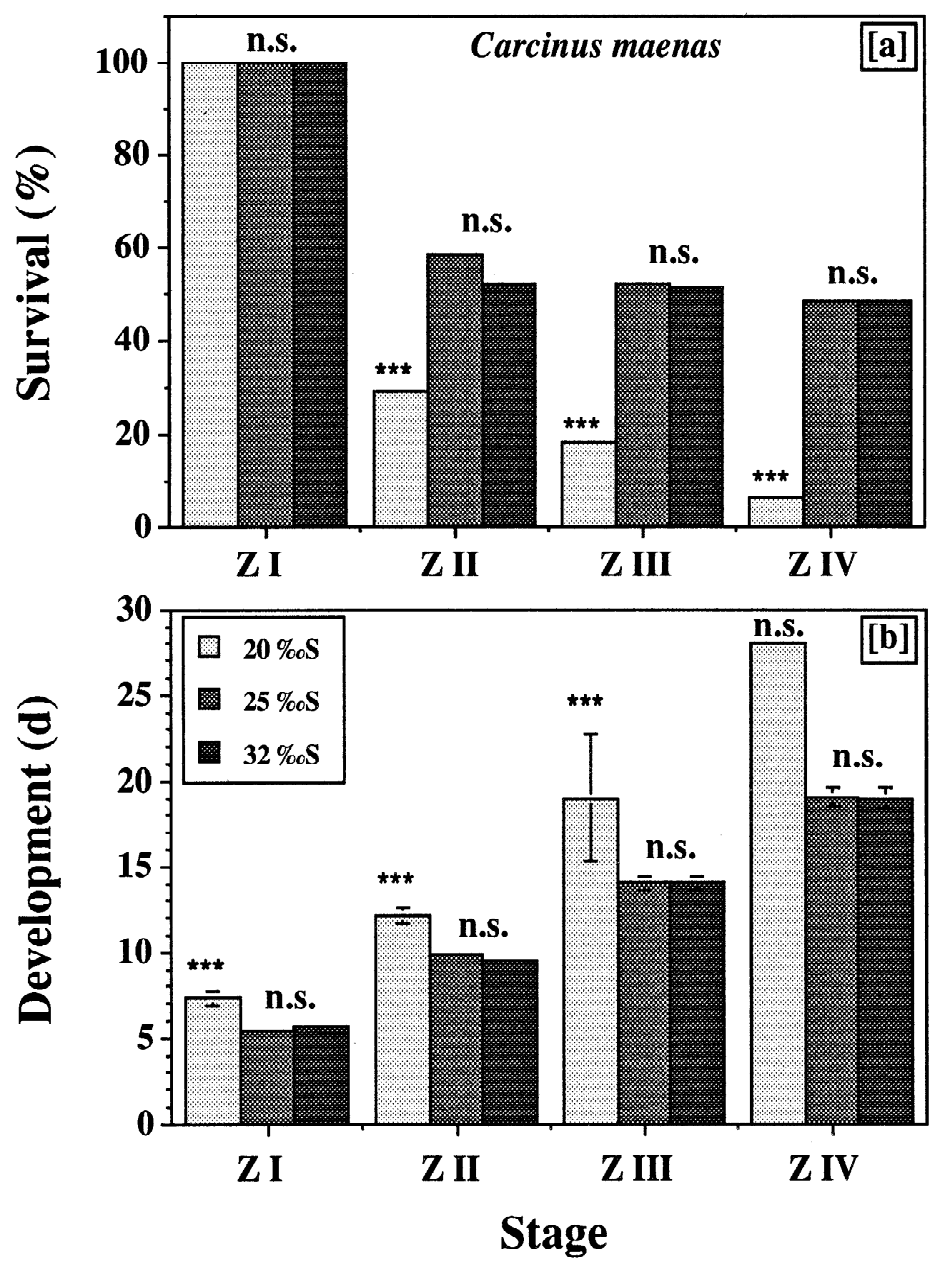

Fig. 1. Carcinus maenas: (a) survival ( $\%$; initial $n=100$ individuals per treatment); (b) cumulative duration of development (days) in successive zoeal stages (Z I-Z IV) reared at three different salinities (20, 25, 32\%o; results of rearing experiment at $15 \%$ omitted: no survival beyond first stage). Error bars (in some cases too small to appear in graph): $\bar{x} \pm 95 \%$ confidence intervals; statistically significant differences marked with asterisks: $* * *, * * *(=P<0.05,<0.01,<0.001)$; n.s. $=$ statistically not significant (in Z IV, $20 \%$ : n.s. because of low number of survivors). 
cumulative mortality, while no significant differences in rates of survival or development were observed between the 25 and $32 \%$ o treatments (Fig. 1).

The data of early larval growth and respiration are compiled in Table 1. Highly significant changes in biomass and metabolic rates were found on different days of development and among different salinity treatments. In growth, these changes were more conspicuous in measurements of dry weight $(W)$, carbon $(C)$ and hydrogen $(H)$ than in those of nitrogen $(N)$. Fig. 2a shows, as an example, changes in the $C$ content per individual. As a general trend, the amounts of accumulated $C$ increased significantly with increasing salinity. At both 32 and 25\%o, highly significant $C$ growth was observed during the first 2 days of the moult cycle (i.e. in postmoult and early intermoult, stages A-C), while a smaller increase was measured thereafter (in premoult, stage D). This is in contrast to the $20 \%$ o treatment, where no significant increase in the larval $\mathrm{C}$ content

Table 1

Carcinus maenas, Zoea I: larval dry weight $(W)$, carbon $(C)$, nitrogen $(N)$, hydrogen $(H), C: N$ weight ratio, and respiration $(R)$ at four different salinities $(15,20,25,32 \%), 0,2$, and 4 days after hatching

\begin{tabular}{|c|c|c|c|c|c|c|c|c|c|}
\hline \multirow[t]{3}{*}{ Parameter } & \multirow[t]{3}{*}{ Day } & \multicolumn{8}{|c|}{ Salinity $(\% o)$} \\
\hline & & \multicolumn{2}{|l|}{15} & \multicolumn{2}{|l|}{20} & \multicolumn{2}{|l|}{25} & \multicolumn{2}{|l|}{32} \\
\hline & & $\bar{x}$ & \pm & $\bar{x}$ & \pm & $\bar{x}$ & \pm & $\bar{x}$ & \pm \\
\hline \multirow[t]{3}{*}{$W(\mu \mathrm{g} /$ ind $)$} & 0 & & & & & & & 9.7 & 0.3 \\
\hline & 2 & 6.5 & 0.6 & 10.9 & 0.7 & 12.7 & 0.4 & 12.7 & 0.4 \\
\hline & 4 & 8.7 & 0.4 & 11.5 & 0.4 & 12.6 & 0.4 & 13.9 & 0.7 \\
\hline \multirow[t]{3}{*}{$C(\mu \mathrm{g} /$ ind $)$} & 0 & & & & & & & 3.4 & 0.1 \\
\hline & 2 & 2.4 & 0.2 & 3.5 & 0.2 & 4.3 & 0.1 & 4.6 & 0.1 \\
\hline & 4 & 2.9 & 0.1 & 3.9 & 0.2 & 4.5 & 0.1 & 5.0 & 0.3 \\
\hline \multirow[t]{3}{*}{$N(\mu \mathrm{g} /$ ind $)$} & 0 & & & & & & & 0.80 & 0.01 \\
\hline & 2 & 0.60 & 0.10 & 0.80 & 0.10 & 1.00 & 0.01 & 1.10 & 0.01 \\
\hline & 4 & 0.70 & 0.01 & 0.90 & 0.10 & 1.10 & 0.01 & 1.20 & 0.10 \\
\hline \multirow[t]{3}{*}{$H(\mu \mathrm{g} / \mathrm{ind})$} & 0 & & & & & & & 0.50 & 0.10 \\
\hline & 2 & 0.40 & 0.01 & 0.50 & 0.01 & 0.70 & 0.00 & 0.70 & 0.01 \\
\hline & 4 & 0.40 & 0.01 & 0.60 & 0.10 & 0.70 & 0.00 & 0.70 & 0.01 \\
\hline \multirow[t]{3}{*}{$C(\% W)$} & 0 & & & & & & & 34.7 & 0.6 \\
\hline & 2 & 38.0 & 2.1 & 31.8 & 0.6 & 33.5 & 0.5 & 33.9 & 0.6 \\
\hline & 4 & 33.3 & 0.7 & 34.1 & 0.7 & 35.5 & 0.7 & 35.5 & 0.9 \\
\hline \multirow[t]{3}{*}{$N(\% W)$} & 0 & & & & & & & 8.3 & 0.3 \\
\hline & 2 & 9.7 & 1.1 & 7.3 & 0.3 & 7.7 & 0.2 & 7.8 & 0.1 \\
\hline & 4 & 8.0 & 0.3 & 8.1 & 0.1 & 8.6 & 0.3 & 8.7 & 0.2 \\
\hline \multirow[t]{3}{*}{$H(\% W)$} & 0 & & & & & & & 5.4 & 0.5 \\
\hline & 2 & 5.8 & 0.4 & 4.8 & 0.1 & 5.2 & 0.1 & 5.3 & 0.1 \\
\hline & 4 & 5.0 & 0.1 & 5.1 & 0.3 & 5.2 & 0.2 & 5.3 & 0.1 \\
\hline \multirow[t]{3}{*}{$C: N$ ratio } & 0 & & & & & & & 4.20 & 0.16 \\
\hline & 2 & 3.93 & 0.21 & 4.37 & 0.17 & 4.37 & 0.07 & 4.35 & 0.03 \\
\hline & 4 & 4.18 & 0.09 & 4.21 & 0.06 & 4.14 & 0.10 & 4.07 & 0.02 \\
\hline \multirow[t]{3}{*}{$R\left(\mu \mathrm{g} \mathrm{O}_{2} \cdot \mathrm{h}^{-1} \cdot\right.$ ind $\left.^{-1}\right)$} & 0 & 0.031 & 0.003 & 0.025 & 0.002 & 0.025 & 0.030 & 0.044 & 0.003 \\
\hline & 2 & 0.022 & 0.005 & 0.031 & 0.004 & 0.040 & 0.004 & 0.040 & 0.008 \\
\hline & 4 & 0.027 & 0.004 & 0.037 & 0.007 & 0.060 & 0.005 & 0.060 & 0.003 \\
\hline
\end{tabular}

$C, N, H$ given in $\mu \mathrm{g}$ per individual and in $\%$ of $W ; \pm \mathrm{SD}$, with $n=8$ replicate determinations in $R, n=6$ in all other measurements. Biomass data for 0 days given in the $32 \%$ column only (salinity at hatching). 

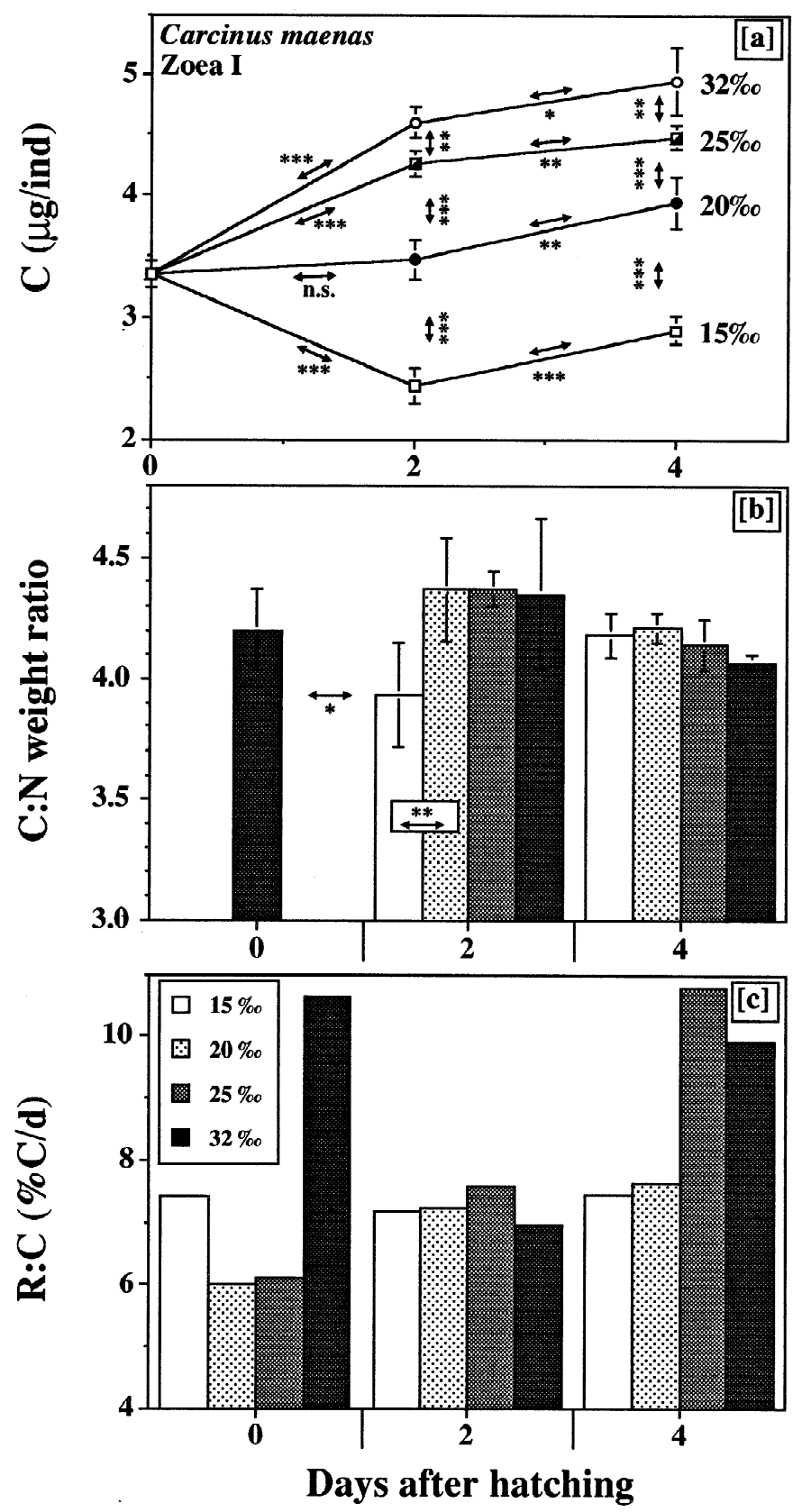

Fig. 2. Carcinus maenas: (a) carbon content ( $C, \mu \mathrm{g} /$ individual); (b) carbon:nitrogen weight ratio $(C: N)$; and (c) carbon-specific metabolic losses (in $\%$ of body- $C$ per day) in the Zoea I stage reared at four different salinities $(15,20,25,32 \%$ ) . Error bars, asterisks: see Fig. 1 for explanation. 
was observed during the first half of the Zoea I moult cycle, but during the second half. The growth pattern at $15 \%$ was again different: during the first 2 days after hatching, significant $C$ losses took place, followed by an increase thereafter (Fig. 2a). This final phase of growth, however, was not sufficient to allow for a successful moulting to the Zoea II instar; the larvae died when they approached ecdysis.

Changes in individual larval biomass were accompanied by those in the relative elemental composition (Table 1). The $C: N$ ratio, which is considered an indicator of the lipid:protein ratio, indicates that the initial loss and subsequent gain in $C$ observed at $15 \%$ were probably caused by an initial degradation of lipids, followed by a partial restoration. In contrast, the $N$ fraction, which is primarily associated with proteins, remained more stable (Table 1; Fig. 2b). According to the $C: N$ index, the larvae that were reared at higher salinities showed an inverse pattern, i.e. a particularly fast accumulation of lipids during postmoult and intermoult followed by a period of proportionally decreasing lipid (or increasing protein) contents during premoult (Fig. 2b).

Immediately after hatching (day 0; Table 1), individual respiration rates $(R)$ were maximum in larvae which remained at constant $32 \%$, the second highest value was measured after transference to the lowest salinity (15\%o), and significantly lower figures were observed at intermediate salinities $(20,25 \%$ o). Similar patterns were found at 15 and 32\%o, with $R$ decreasing after 2 days of development, and increasing towards the end of the moulting cycle (days 2, 4; Table 1). At intermediate salinities $(20,25 \%$ ), in contrast, $R$ increased significantly throughout development in the Zoea I instar. The average level of respiration increased with increasing salinity (Table 1).

Since larval biomass per individual was initially the same in all four experimental groups, the response pattern in weight-specific metabolic rates $\left(Q_{\mathrm{O}_{2}}\right)$ of freshly hatched zoeae was the same as in the individual respiration rates ( $R$; see above). At 20 and $25 \%$, the initial $Q_{\mathrm{O}_{2}}$ values were about $2.6 \mu \mathrm{g} \mathrm{O} \mathrm{O}_{2} \cdot \mathrm{h}^{-1} \cdot \mathrm{mg}^{-1}$, those at 15 and $32 \%$ were 3.2 and 4.6, respectively. In the middle of the moult cycle (2 days after hatching), $Q_{\mathrm{O}_{2}}$ was in all salinity treatments about $3.0 \mu \mathrm{g} \mathrm{O}_{2} \cdot \mathrm{h}^{-1} \cdot \mathrm{mg}^{-1}$. While this value remained constant at 15 and 20\%o, a final increase in $Q_{\mathrm{O}_{2}}$ was observed at higher salinities, reaching 4.4 and $4.7 \mu \mathrm{g} \mathrm{O}_{2} \cdot \mathrm{h}^{-1} \cdot \mathrm{mg}^{-1}$ at 25 and $32 \%$, respectively.

When rates of oxygen consumption are converted to respiratory carbon losses (see Section 2), $C$-specific metabolic rates, $R: C$, can be calculated (expressed as a percentage of body $C$ respired per day). Developmental and salinity-induced changes in this index of metabolic carbon turnover are depicted in Fig. 2c. Most $R: C$ values ranged from about 6 to $8 \%$ of body $C$ respired per day. Maximum figures (ca. $10-11 \% \cdot$ day $^{-1}$ ) were measured in freshly hatched zoeae kept at 32\%o, and in premoult (4-day old) Zoea I larvae reared at 25 and $32 \%$ (Fig. 2c). While conspicuous developmental changes in metabolic $C$ loss occurred at 25 and $32 \%$, almost constant values were found at lower salinities (Fig. 2c).

The data of growth and metabolism (Table 1, Fig. 2) can be integrated over two equally long periods, comprising days $0-2$ and 2-4, respectively, to depict developmental differences in carbon partitioning during the first half (stages $\mathrm{A}-\mathrm{C}$ ) and the second half (stages $\mathrm{D}_{0}-\mathrm{D}_{4}$ ) of the Zoea I moult cycle (Fig. 3). These integrated data show, more clearly than point measurements of larval biomass and metabolism, the interaction 

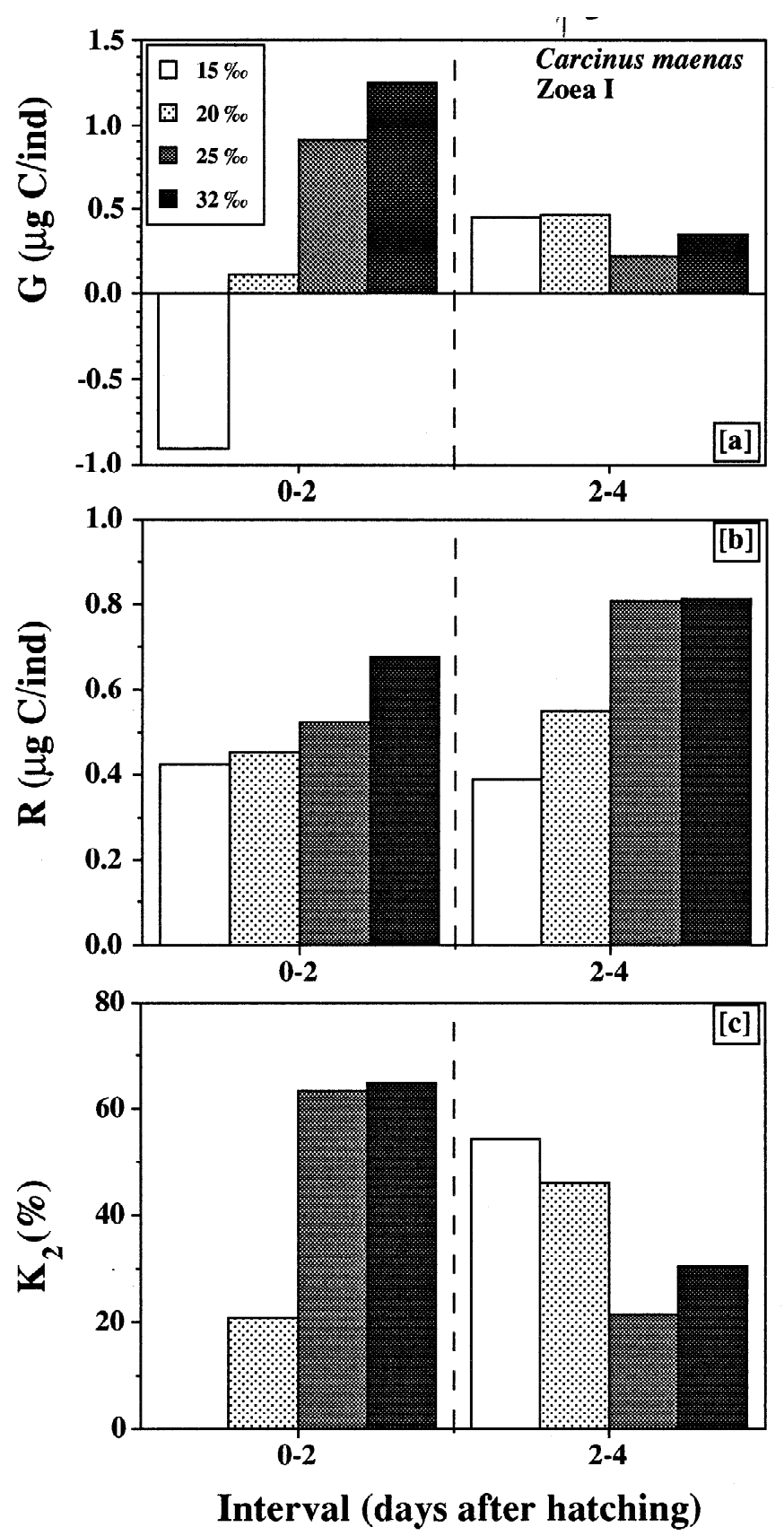

Fig. 3. Carcinus maenas: partial carbon budget during two intervals of the moulting cycle (days 0-2, 2-4) in the Zoea I stage reared at four different salinities $(15,20,25,32 \%$ ). (a) Growth $(G)$, (b) respiration $(R)$, in $\mu \mathrm{g}$ $C$ per 2-day interval; (c) net growth efficiency $\left(K_{2}\right.$, in \%). 
between moult-cycle-related (intrinsic) and salinity-related (extrinsic) factors. While highly significant effects of salinity were observed in the first half of the moult cycle (statistical tests: cf. Fig. 2a), similar rates of biomass increase in all treatments were measured during the second period (Fig. 3a). Fig. 3b indicates that these patterns of $C$ accumulation or loss, respectively, were not correlated with metabolic $C$ losses (calculated from average $R$ values; Table 1). The latter increased during both parts of the moult cycle with increasing salinity and, at all salinities except $15 \%$, with the time of development.

Assuming that no significant excretion of substances other than ammonia occurred in the crab larvae (Anger, 1991), the sum of growth and respiration (expressed in units of carbon, $C$, per interval of time; Fig. 3a, b) is an estimate of $C$ assimilation. During days 0-2 of the moult cycle, assimilation increased greatly with increasing salinity, but in the premoult period (days $2-4$ ). In contrast, at salinities $\leq 20 \%$, assimilation was initially low, but increased during premoult. At higher salinities it was maximum in early stages of the moult cycle. These patterns of change correspond, in general, with those in growth, suggesting that variation in growth was primarily a consequence of changing assimilation rates. At $15 \%$, the initial $C$ losses estimated from larval oxygen consumption amounted to only half the losses that were measured in biomass (Fig. 3a,b); this inconsistency in our results will be discussed below.

From the assimilation and growth values, $C$-based net growth efficiency $\left(K_{2}\right)$ can be calculated. Changes in this index of $C$ partitioning show that the depression of larval growth at reduced salinities (Fig. 3a) was caused not only by a depression of the overall assimilation capacity, but also by a decreasing $K_{2}$ (Fig. $3 c$ ). At salinities $\leq 20 \%$, freshly hatched larvae thus assimilated a lesser amount of organic matter from food, and a lower proportion of this was converted to tissue growth. The larvae which survived at salinities $\leq 20 \%$ o beyond the intermoult stage, showed later in the moult cycle an increasing assimilation and $K_{2}$. However, this sufficed for only a partial compensation of preceding losses in larval biomass (Fig. 2a) and did not allow for successful development through ecdysis at $15 \%$.

\subsection{Transitory exposure to reduced salinities}

In our second series of experiments (1993), we exposed freshly hatched Carcinus maenas larvae for differential initial periods to a reduced salinity (20\%o). This set of treatments should roughly mimic larval hatching in an estuary, followed by later downstream transport towards the sea (Fig. 4c). Treatments A and E in this set of experiments were identical with the constant 32 and $20 \%$ o treatments in the first series (1991). Direct comparison showed that the larvae from the first hatch had, in general, a higher survival rate, but a slower development through the Zoea I stage. The initial biomass and subsequent growth were significantly higher, but average respiration rates were lower in the 1993 hatch (Tables 1 and 2). The response to reduced salinity (20\%o) was similar in these two hatches, consistently showing signs of osmotic stress. With increasing duration of initial exposure, the survival tended to decrease (Fig. 4a), while the duration of development to the Zoea II instar increased significantly (Fig. 4b).

As in the 1991 experiments, significant changes of biomass, chemical composition, 

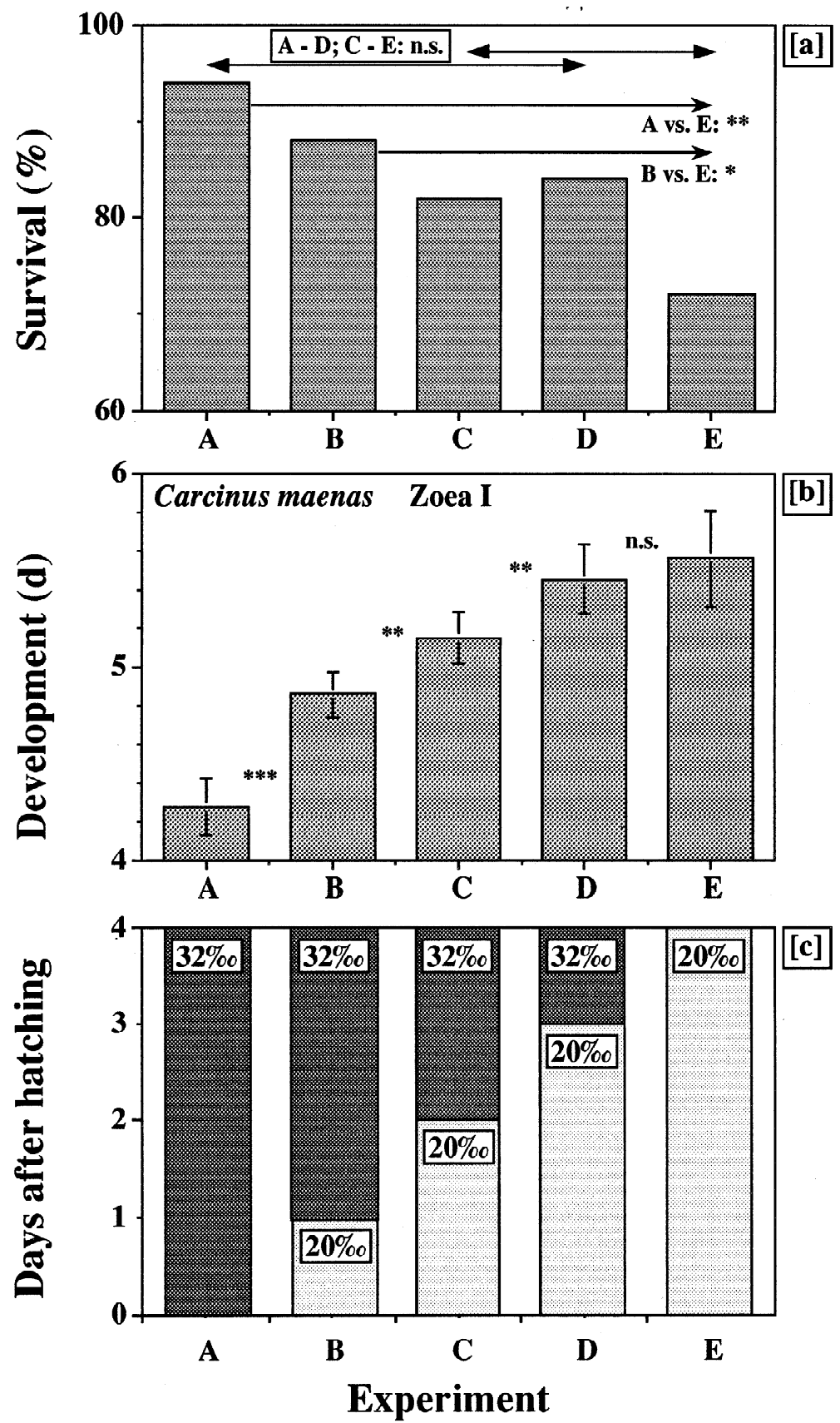

Fig. 4. Carcinus maenas: (a) survival (\%; initial $n=50$ individuals per treatment); (b) cumulative duration of development (days) of the Zoea I stage in five different salinity treatments (experiments A-E); (c) experimental design (for more detailed explanation see text). Error bars, asterisks: see Fig. 1 for explanation. 
Table 2

Carcinus maenas, Zoea I: larval dry weight $(W)$, carbon $(C)$, nitrogen $(N)$, hydrogen $(H), C: N$ weight ratio, and respiration $(R)$ at four experimental treatments (A-E) during development from hatching (day 0$)$ to late premoult (day 5)

\begin{tabular}{|c|c|c|c|c|c|c|c|c|c|c|c|}
\hline \multirow[t]{3}{*}{ Parameter } & \multirow[t]{3}{*}{ Day } & \multicolumn{10}{|c|}{ Experiment } \\
\hline & & \multicolumn{2}{|l|}{$\mathrm{A}$} & \multicolumn{2}{|l|}{ B } & \multicolumn{2}{|l|}{$\mathrm{C}$} & \multicolumn{2}{|l|}{$\mathrm{D}$} & \multicolumn{2}{|l|}{$\mathrm{E}$} \\
\hline & & $\bar{x}$ & \pm & $\bar{x}$ & \pm & $\bar{x}$ & \pm & $\bar{x}$ & \pm & $\bar{x}$ & \pm \\
\hline \multirow[t]{6}{*}{$W(\mu \mathrm{g} /$ ind $)$} & 0 & 10.4 & 0.3 & & & & & & & & \\
\hline & 1 & 13.3 & 0.5 & & & & & & & 12.1 & 0.3 \\
\hline & 2 & 15.7 & 0.4 & 13.6 & 0.4 & & & & & 13.0 & 0.5 \\
\hline & 3 & 15.9 & 0.3 & 13.9 & 0.7 & 13.5 & 0.5 & & & 13.5 & 0.4 \\
\hline & 4 & 15.3 & 0.6 & 14.7 & 0.3 & 14.8 & 0.2 & 14.4 & 0.3 & 13.9 & 0.8 \\
\hline & 5 & & & 13.1 & 0.7 & 12.9 & 0.3 & 13.0 & 0.4 & 11.0 & 0.9 \\
\hline \multirow{6}{*}{$C(\mu \mathrm{g} /$ ind $)$} & 0 & 3.6 & 0.1 & & & & & & & & \\
\hline & 1 & 4.4 & 0.2 & & & & & & & 3.9 & 0.1 \\
\hline & 2 & 5.2 & 0.2 & 4.4 & 0.2 & & & & & 4.3 & 0.2 \\
\hline & 3 & 5.6 & 0.1 & 4.6 & 0.3 & 4.7 & 0.3 & & & 4.5 & 0.1 \\
\hline & 4 & 5.3 & 0.3 & 4.8 & 0.2 & 4.8 & 0.1 & 4.7 & 0.1 & 4.7 & 0.1 \\
\hline & 5 & & & 4.6 & 0.1 & 4.4 & 0.2 & 4.5 & 0.3 & 4.1 & 0.3 \\
\hline \multirow{6}{*}{$N(\mu \mathrm{g} /$ ind $)$} & 0 & 0.85 & 0.03 & & & & & & & & \\
\hline & 1 & 0.97 & 0.03 & & & & & & & 0.88 & 0.02 \\
\hline & 2 & 1.12 & 0.04 & 0.95 & 0.03 & & & & & 0.94 & 0.04 \\
\hline & 3 & 1.24 & 0.02 & 1.01 & 0.07 & 1.05 & 0.07 & & & 1.01 & 0.02 \\
\hline & 4 & 1.24 & 0.07 & 1.10 & 0.04 & 1.13 & 0.02 & 1.10 & 0.02 & 1.08 & 0.02 \\
\hline & 5 & & & 1.10 & 0.03 & 1.07 & 0.04 & 1.07 & 0.04 & 0.97 & 0.08 \\
\hline \multirow[t]{6}{*}{$H(\mu \mathrm{g} /$ ind $)$} & 0 & 0.49 & 0.02 & & & & & & & & \\
\hline & 1 & 0.58 & 0.03 & & & & & & & 0.49 & 0.02 \\
\hline & 2 & 0.71 & 0.04 & 0.64 & 0.04 & & & & & 0.53 & 0.03 \\
\hline & 3 & 0.83 & 0.05 & 0.67 & 0.06 & 0.71 & 0.05 & & & 0.67 & 0.06 \\
\hline & 4 & 0.78 & 0.06 & 0.68 & 0.03 & 0.67 & 0.02 & 0.62 & 0.07 & 0.66 & 0.02 \\
\hline & 5 & & & 0.70 & 0.02 & 0.66 & 0.03 & 0.65 & 0.33 & 0.57 & 0.05 \\
\hline \multirow[t]{6}{*}{$C(\% W)$} & 0 & 35.0 & 0.7 & & & & & & & & \\
\hline & 1 & 32.8 & 0.3 & & & & & & & 31.9 & 1.2 \\
\hline & 2 & 33.3 & 1.1 & 32.7 & 0.7 & & & & & 33.0 & 0.4 \\
\hline & 3 & 35.3 & 0.4 & 33.1 & 0.8 & 34.5 & 2.1 & & & 33.2 & 0.4 \\
\hline & 4 & 34.7 & 0.8 & 32.4 & 0.7 & 32.7 & 0.5 & 33.0 & 0.6 & 33.8 & 2.9 \\
\hline & 5 & & & 35.4 & 0.9 & 34.0 & 1.0 & 34.4 & 1.5 & 37.5 & 0.6 \\
\hline \multirow[t]{6}{*}{$N(\% W)$} & 0 & 8.2 & 0.1 & & & & & & & & \\
\hline & 1 & 7.3 & 0.1 & & & & & & & 7.3 & 0.3 \\
\hline & 2 & 7.1 & 0.2 & 7.0 & 0.2 & & & & & 7.2 & 0.1 \\
\hline & 3 & 7.8 & 0.1 & 7.2 & 0.2 & 7.7 & 0.4 & & & 7.5 & 0.1 \\
\hline & 4 & 8.1 & 0.2 & 7.5 & 0.2 & 7.6 & 0.1 & 7.6 & 0.2 & 7.8 & 0.6 \\
\hline & 5 & & & 8.4 & 0.3 & 8.3 & 0.3 & 8.2 & 0.2 & 9.0 & 0.1 \\
\hline \multirow[t]{6}{*}{$H(\% W)$} & 0 & 4.7 & 0.2 & & & & & & & & \\
\hline & 1 & 4.4 & 0.1 & & & & & & & 4.1 & 0.2 \\
\hline & 2 & 4.5 & 0.3 & 4.7 & 0.2 & & & & & 4.1 & 0.1 \\
\hline & 3 & 5.2 & 0.2 & 4.8 & 0.2 & 5.2 & 0.3 & & & 5.0 & 0.4 \\
\hline & 4 & 5.1 & 0.2 & 4.6 & 0.2 & 4.5 & 0.1 & 4.3 & 0.5 & 4.8 & 0.5 \\
\hline & 5 & & & 5.4 & 0.2 & 5.1 & 0.2 & 5.0 & 0.2 & 5.3 & 0.1 \\
\hline \multirow[t]{6}{*}{$C: N$ ratio } & 0 & 4.27 & 0.06 & & & & & & & & \\
\hline & 1 & 4.48 & 0.07 & & & & & & & 4.41 & 0.03 \\
\hline & 2 & 4.69 & 0.04 & 4.69 & 0.03 & & & & & 4.58 & 0.07 \\
\hline & 3 & 4.54 & 0.04 & 4.58 & 0.04 & 4.46 & 0.05 & & & 4.43 & 0.02 \\
\hline & 4 & 4.27 & 0.03 & 4.33 & 0.02 & 4.28 & 0.03 & 4.32 & 0.03 & 4.32 & 0.04 \\
\hline & 5 & & & 4.20 & 0.04 & 4.08 & 0.03 & 4.19 & 0.14 & 4.19 & 0.02 \\
\hline$R\left(\mu \mathrm{g} \mathrm{O}_{2} \cdot \mathrm{h}^{-1} \cdot\right.$ ind $\left.^{-1}\right)$ & 0 & 0.039 & 0.006 & & & & & & & 0.042 & 0.007 \\
\hline & 1 & 0.042 & 0.003 & 0.036 & 0.005 & & & & & 0.041 & 0.002 \\
\hline & 2 & 0.060 & 0.004 & 0.041 & 0.003 & 0.048 & 0.008 & & & 0.048 & 0.009 \\
\hline & 3 & 0.082 & 0.007 & 0.059 & 0.003 & 0.059 & 0.005 & 0.045 & 0.006 & 0.046 & 0.005 \\
\hline
\end{tabular}

$C, N, H$ given in $\mu \mathrm{g}$ per individual and in $\%$ of $W ; \pm \mathrm{SD}$, with $n=8$ replicate determinations in $R, n=6$ in all other measurements. Treatments: A, constant 32\%o; E, constant 20\%o; B-D, 32\%o after differential periods of initial exposure to $20 \%$ (B) 1 day; (C) 2 days; (D) 3 days; cf. Fig. 4c for experimental design). No biomass measurements for Exp. A, day 5, as most individuals moulted on day 5; no $R$ measurements after day 3 (all Exps.), because first moults occurred in Winkler bottles on day 4. Data for 0 days given in the Exp. A column only (salinity at hatching, 32\%o); other missing values in Exps. B-D, identical with Exp. E. 
and metabolism were found during the time of development in the Zoea I moult cycle, and in response to reduced salinity (Table 2). The patterns of growth (described as changes in $W, C, N, H$ per individual during the time of development) were similar as those described by Dawirs et al. (1986), i.e. with high initial biomass increments in the postmoult and intermoult stages, but constant or decreasing values in later stages of the moult cycle (premoult). The average level of larval biomass was highest at 32\%o (treatment A) and lowest at 20\%o (E), while intermediate figures were observed in treatments with transitory exposure to $20 \%$ (B-D). As in the 1991 series of experiments, a depression of growth was most conspicuous during the initial phase of the Zoea I moult cycle. Larval biomass increased consistently after re-transfer from 20 to $32 \%$ as compared with the $20 \%$ control group (E), but remained significantly lower than at constant 32\%o (Table 2, treatment A).

During the course of development in sea water, significantly increasing respiration rates $(R)$ were measured in the Zoea $\mathrm{I}$, in particular in premoult (Table 2, treatment $\mathrm{A}$ ). At $20 \%$, in contrast, larval oxygen consumption remained low throughout the moult cycle. After re-transfer to $32 \%, R$ increased in treatments $\mathrm{B}$ and $\mathrm{C}$, but not after a prolonged exposure to $20 \%$ (Table 2, treatment D). Weight-specific metabolic rates $\left(Q_{\mathrm{O}_{2}}\right)$ can be calculated from $R$ and $W$ values given in Table 2. They show similar patterns of change as the individual rates $(R) . Q_{\mathrm{O}_{2}}$ varied in this series of experiments between 3.0 and $5.2 \mu \mathrm{g} \mathrm{O}_{2} \cdot \mathrm{mg}^{-1} \cdot \mathrm{h}^{-1}$. The most conspicuous changes were observed in premoult (3 days old) larvae, with a maximum in sea water (treatment $A$ ), lowest values at $20 \%$ (E), and intermediate figures in treatments B and C. No significant response to late re-transfer to $32 \%$ was observed in treatment $\mathrm{D}$, i.e. $Q_{\mathrm{O}_{2}}$ remained similarly low as in group $\mathrm{E}$.

As in the 1991 experiments, the data of growth and respiration (Table 2) allow for the construction of a partial carbon budget (Fig. 5). When total $C$ increments during the Zoea I moult cycle (i.e. the differences between initial and final $C$ values, Table 2) are compared in different experimental treatments, a reduction of growth by 29 to $38 \%$ can be seen in those larvae, which were temporarily or continually exposed to $20 \%$ as compared with the sea water control group, A (Fig. 5a). In all treatments, however, there were final biomass losses in late premoult, after having reached a maximum about 4 days after hatching. Hence, total net $C$ increments from the beginning until the end of the Zoea I moult cycle were lower than the maximum growth (Table 2). When this maximum figure is compared among treatments, the larvae in experiments B-D revealed a reduction in growth by 41 to $53 \%$; a constant exposure to $20 \%$ (treatment E) caused a reduction by $71 \%$ compared with the sea water control.

Again, figures of depressed growth did not coincide with enhanced metabolic losses per individual $(R)$ or per unit of biomass $\left(Q_{\mathrm{O}_{2}}\right)$. Fig. 5b shows that respiratory $C$ losses were, on average, about $20 \%$ lower in treatments B-E as compared with those in experiment $\mathrm{A}$. In consequence, the sum of respiration and growth (assimilation) decreased in all treatments with an exposure to a reduced salinity (B-E). In addition to this reduction in assimilation, the larvae in treatments B-E showed also a reduced net growth efficiency $\left(K_{2}\right.$; Fig. 5c). A continuous exposure to $20 \%$ o caused stronger effects than a transitory exposure $(\mathrm{B}-\mathrm{D})$. 

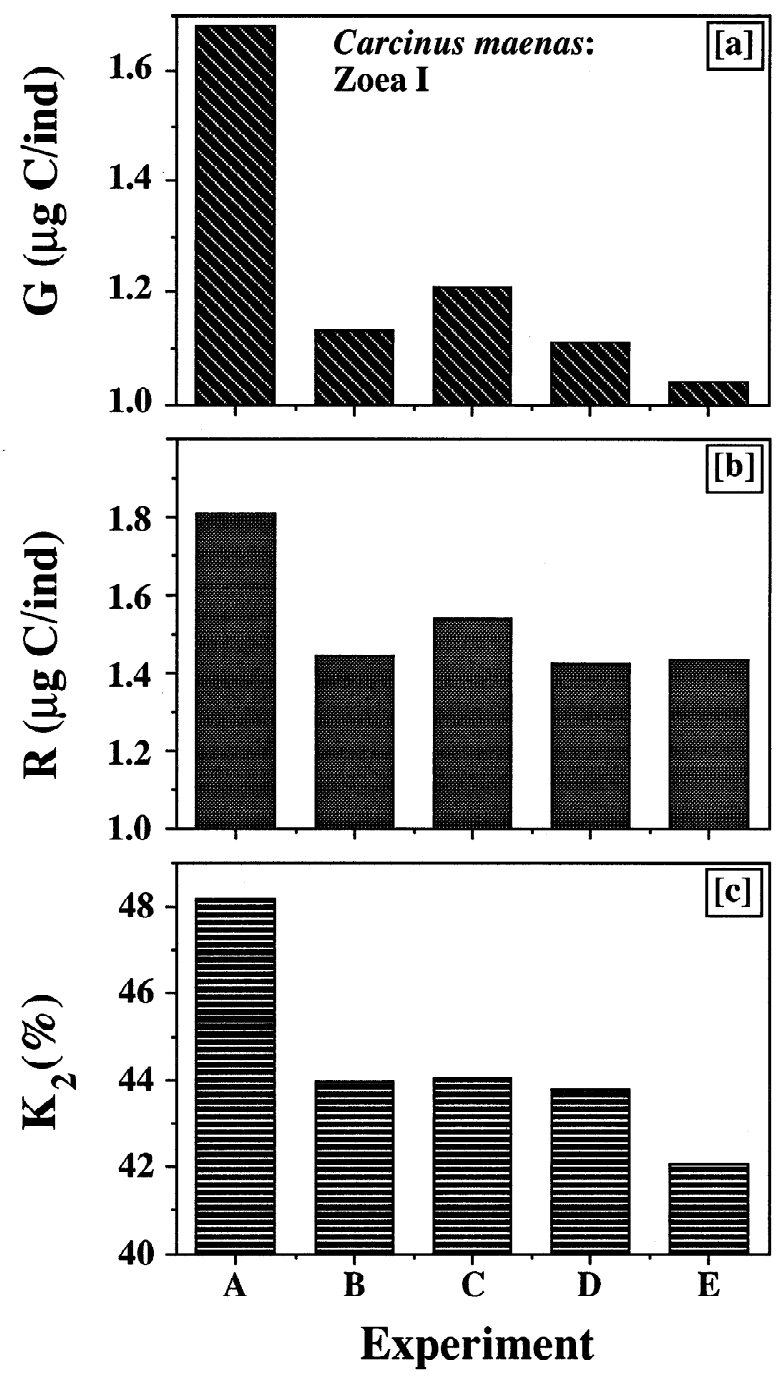

Fig. 5. Carcinus maenas: partial carbon budget (cumulative) for the Zoea I stage in five different salinity treatments (experiments A-E; for experimental design see Fig. 4c). (a) Growth $(G)$, (b) respiration $(R)$, in $\mu \mathrm{g}$ $C$; (c) net growth efficiency $\left(K_{2}\right.$, in \%).

\section{Discussion}

Our experiments show that shore crab (Carcinus maenas) larvae from a North Sea population respond sensitively against continuous or even short-term transitory exposure to reduced salinities $\leq 20 \%$. Significant decreases were found in the rates of early zoeal survival, development, growth, respiration, and assimilation. Since the rate of oxygen consumption per larva tended to decrease at low salinities, the concurrent depression of 
larval growth cannot be explained with enhanced metabolic demands under hypoosmotic stress. Rather, this was a consequence of a reduced assimilation capacity; future measurements of larval ingestion rates at different salinities should show whether this was a consequence of decreasing food uptake, decreasing conversion efficiency, or both. As an additional effect, there was a shift in energy partitioning: net growth efficiency $\left(K_{2}\right)$ decreased under the influence of reduced salinities. Thus, the larvae not only assimilated less organic matter from ingested food, but also converted a proportionally lesser part of the assimilated matter into tissue growth.

Larval growth was particularly affected by hypo-osmotic stress during the initial phase (postmoult, intermoult) of the Zoea I moult cycle. Those larvae, which survived at $15 \%$ o salinity through the intermoult-premoult transition, were in general able to continue their development until they reached the final stages of premoult $\left(\mathrm{D}_{3-4}\right)$. During the second half of the moulting cycle, they were able to accumulate significant amounts of organic matter, although this growth was not sufficient to allow for successful development through ecdysis. The larvae died when they attempted to moult to the second zoeal stage. This response pattern resembles that observed under temporary food limitation: similar to the case of nutritional stress, the transitions between moult cycle stages $C$ and $D_{0}$ (the ' $D_{0}$ threshold'; Anger, 1987) and between the end of premoult and ecdysis (the 'exuviation threshold') may thus be critical points also with respect to hypo-osmotic, and possibly, other kinds of stress.

Since insufficient information is available on interactions of intrinsic (e.g. moult-cycle related) and extrinsic factors in crustacean larvae, a closer investigation of such interactions, including differentially sensitive periods of development, should improve our understanding of larval survival under variable ecological conditions during hatching and subsequent transport in the water column. This approach will require increasingly complex experimental designs, especially, when also other environmental key factors such as food availability are considered (e.g. Factor and Dexter, 1993; Harms et al., 1994). Among the intrinsic factors, the ontogeny of osmoregulation, especially, needs further investigation, i.e. the development of regulatory structures (Hong, 1988; Bouaricha et al., 1994) and endocrine systems (Charmantier et al., 1988; Bouaricha et al., 1991; Charmantier and Charmantier-Daures, 1991). In our study, larval respiration was in general reduced at low salinities. According to the current understanding of the relationships between osmoregulation and energy metabolism (e.g. Florkin, 1960; Potts and Parry, 1964; Kinne, 1971), this response suggests a very low or lacking osmoregulatory capacity in early shore crab larvae, at least in those from a North Sea population.

A major discrepancy occurred between our data of growth and respiration at $15 \%$ : initial biomass losses calculated from $\mathrm{CHN}$ analyses were about twice as high as the metabolic losses estimated from oxygen consumption (Figs. 3a and b). This may partly be explained by possible sampling of moribund larvae, which would cause an underestimation of average larval biomass and oxygen consumption. From such errors, an overestimation of the actual losses of body $C$ would result, combined with an underestimation of metabolic losses. As an additional source of error, our estimate of the respiratory quotient $(\mathrm{RQ}=0.9$; see Section 2) might be too low; however, this would have only little influence on the calculation of metabolic $C$ losses. As another possible 
source of error, excretory losses of organic matter, namely amino acids, are conceivable too under conditions of hypo-osmotic stress.

Estuarine crab populations living adjacent to the North Sea or the Atlantic have evolved behavioural mechanisms such as tide-related larval release rhythms (Queiroga et al., 1994) and endogenous vertical tidal migration rhythms (Zeng and Naylor, 1996a,b,c). Utilising the net outflow of estuarine waters during ebb tides, these mechanisms ensure a rapid export of pelagic larvae to coastal marine waters with higher salinity. In contrast, the larvae of Baltic Sea crabs might have evolved physiological adaptations to low salinity conditions, as tides are practically absent, and there is (compared with lower estuaries) only a slow and irregular outflow of Baltic Sea water towards the North Sea. Comparative studies (Theede, 1969) have shown that adult crabs from the Baltic Sea have a higher capacity of hyper-osmoregulation than conspecifics from the North Sea. This difference is only partially reversible by cross-wise adaptation to higher or lower salinities, suggesting genetic differences. While such intraspecific physiological variation between geographically separated populations (Baltic Sea vs. North Sea; Theede, 1969) or between different colour morphs (McGaw and Naylor, 1992a,b) has been studied in adult C. maenas, nothing is known about possible divergence in the response of larval stages. We thus plan to compare the tolerance of larval shore crab from the Baltic and North Sea after differential adaptation of eggs, thus including effects of non-genetic resistance adaptation during embryonic development (Kinne, 1964, 1971).

\section{Acknowledgements}

This investigation was part of a bilateral cooperation programme (MAR-8) between the Universidad Nacional de Mar del Plata, Argentina, and the Biologische Anstalt Helgoland, Germany. It was funded by the Secretaría de Ciencia y Tecnología (Buenos Aires) and, on behalf of the German Federal Ministry of Education, Science and Technology (Bonn) by the International Bureau of the Forschungszentrum Jülich GmbH (Jülich, Germany).

\section{References}

Anger, K., 1983. Moult cycle and morphogenesis in Hyas araneus larvae (Decapoda, Majidae), reared in the laboratory. Helgoländer Meeresunters. 36, 285-302.

Anger, K., 1987. The $\mathrm{D}_{0}$ threshold: a critical point in the larval development of decapod crustaceans. J. Exp. Mar. Biol. Ecol. 108, 15-30.

Anger, K., 1990. Modelling developmental changes in the carbon and nitrogen budgets of larval brachyuran crabs. Helgoländer Meeresunters. 44, 53-80.

Anger, K., 1991. Developmental changes in the bioenergetics of decapod larvae. Mem. Queensl. Mus. 31, 289-308.

Anger, K., 1996. Salinity tolerance of the larvae and first juveniles of a semiterrestrial grapsid crab, Armases miersii (Rathbun). J. Exp. Mar. Biol. Ecol. 202, 205-223. 
Anger, K., Harms, J., Püschel, C., Seeger, B., 1989. Physiological and biochemical changes during the larval development of a brachyuran crab reared under constant conditions in the laboratory. Helgoländer Meeresunters. 43, 225-244.

Barnes, R.S.K., 1994. The Brackish-water Fauna of North-western Europe. An Identification Guide to Brackish-water Habitats, Ecology and Macrofauna for Field Workers, Naturalists and Students. Univ. Press, Cambridge, 287 pp.

Berill, M., 1982. The life cycle of the green crab Carcinus maenas at the northern end of its range. J. Crust. Biol. 2, 31-39.

Bouaricha, N., Charmantier, G., Charmantier-Daures, M., Thuet, P., Trilles, J.-P., 1991. Ontogénèse de l'osmorégulation chez la crevette Penaeus japonicus. Cah. Biol. Mar. 32, 149-158.

Bouaricha, N., Charmantier-Daures, M., Thuet, P., Trilles, J.-P., Charmantier, G., 1994. Ontogeny of osmoregulatory structures in the shrimp Penaeus japonicus (Crustacea, Decapoda). Biol. Bull. 186, 29-40.

Broekhuysen, G.J., 1936. On the development, growth and distribution of Carcinides maenas (L.). Arch. Neerl. Zool. 2, 257-399.

Charmantier, G., Charmantier-Daures, M., 1991. Ontogeny of osmoregulation and salinity tolerance in Cancer irroratus; elements of comparison with C. borealis (Crustacea, Decapoda). Biol. Bull. 180, 125-134.

Charmantier, G., Charmantier-Daures, M., Bouaricha, N., Thuet, P., Aiken, D.E., Trilles, J.-P., 1988. Ontogeny of osmoregulation and salinity tolerance in two decapod crustaceans: Homarus americanus and Penaeus japonicus. Biol. Bull. 175, 102-110.

Christiansen, M.E., 1969. Crustacea Decapoda Brachyura. Marine Invertebrates of Scandinavia 2, Universitetsforlaget Oslo, 1-143.

Cohen, A.D., Carlton, J.T., Fountain, M.C., 1995. Introduction, dispersal and potential impacts of the green crab Carcinus maenas in San Francisco Bay. California Mar. Biol. 122, 225-237.

Crothers, J.H., 1967. The biology of the shore crab Carcinus maenas (L.). I. The background-anatomy, growth and life history. Field Studies 2, 407-434.

Crothers, J.H., 1968. The biology of the shore crab Carcinus maenas (L.). II. The life of the adult crab. Field Studies 2, 579-614.

Dawirs, R.R., Püschel, C., Schorn, F., 1986. Temperature and growth in Carcinus maenas L. (Decapoda: Portunidae) larvae reared in the laboratory from hatching through metamorphosis. J. Exp. Mar. Biol. Ecol. 100, 47-74.

Factor, J.R., Dexter, B.L., 1993. Suspension feeding in larval crabs (Carcinus maenas). J. Mar. Biol. Assoc. UK 73, 207-211.

Florkin, M., 1960. Ecology and metabolism. In: Waterman, T.H. (Ed.), The Physiology of Crustacea, Vol. 1. Academic Press, New York, pp. 395-410.

Foskett, J.K., 1977. Osmoregulation in the larvae and adults of the grapsid crab Sesarma reticulatum Say. Biol. Bull. Mar. Biol. Lab. Woods Hole 153, 505-526.

Green, J., 1968. The Biology of Estuarine Animals. Sigwick and Jackson, London, 401 pp.

Grosholz, E.D., Ruiz, G.M., 1995. Spread and potential impact of the recently introduced European green crab, Carcinus maenas, in central California. Mar. Biol. 122, 239-247.

Harms, J., Meyer-Harms, B., Dawirs, R.R., Anger, K., 1994. Growth and physiology of Carcinus maenas (Decapoda, Portunidae) larvae in the field and in laboratory experiments. Mar. Ecol. Prog. Ser. 108, $107-118$.

Hong, S.Y., 1988. Development of epipods and gills in some pagurids and brachyurans. J. Nat. Hist. 22, 1005-1040.

Kändler, R., 1959. Hydrographische Beobachtungen in der Kieler Förde 1952-1957. Kieler Meeresforsch. 15, 17-28.

Kändler, R., 1961. Über das Vorkommen von Fischbrut, Decapodenlarven und Medusen in der Kieler Förde. Kieler Meeresforsch. 17, 48-64.

Kinne, O., 1964. Non-genetic adaptation to temperature and salinity. Helgoländer Wiss. Meeresunters. 9, 433-458.

Kinne, O., 1971. Salinity: 4.3. Animals; 4.31 Invertebrates. In: Kinne, O. (Ed.), A Comprehensive, Integrated Treatise on Life in Oceans and Coastal Waters, vol. 1. Wiley and Sons, London, pp. 683-1244.

McGaw, I.J., Naylor, E., 1992. Salinity preference of the shore crab Carcinus maenas in relation to coloration during intermoult and to prior acclimation. J. Exp. Mar. Biol. Ecol. 155, 145-159. 
McGaw, I.J., Naylor, E., 1992. The effect of shelter on salinity preference behaviour of the shore crab Carcinus maenas. Mar. Behav. Physiol. 21, 145-152.

Nagaraj, M., 1993. Combined effects of temperature and salinity on the zoeal development of the green crab, Carcinus maenas (Linnaeus, 1758) (Decapoda: Portunidae). Sci. Mar. 57, 1-8.

Potts, W.T.W., Parry, G., 1964. Osmotic and Ionic Regulation in Animals. Pergammon Press, Oxford, 355 pp.

Poulsen, E.M., 1922. On the frequency and distribution of Crangon vulgaris, Carcinus maenas and Portunus holsatus in the Danish coastal waters. Meddr Kommn. Danm. Havunders. Ser. Fiskeri (VI) 7, 1-18.

Queiroga, H., Costlow, J.D., Moreira, M.H., 1994. Larval abundance patterns of Carcinus maenas (Decapoda, Brachyura) in Canal de Mira (Ria de Aveiro, Portugal). Mar. Ecol. Prog. Ser. 111, 63-72.

Rasmussen, E., 1959. Behaviour of sacculinized shore crabs (Carcinus maenas Pennant). Nature 183, 479-480.

Rice, A.L., Ingle, R.W., 1975. The larval development of Carcinus maenas (L.) and C. mediterraneus Czerniavsky (Crustacea, Brachyura, Portunidae) reared in the laboratory. Bull. Br. Mus. Nat. Hist. (Zool.) 28, 103-119.

Sachs, L., 1984. Angewandte Statistik, 6th ed. Springer Verlag, Berlin, Heidelberg, New York, 552 pp.

Sokal, R.R., Rohlf, F.J., 1981. Biometry. The Principles and Practice of Statistics in Biological Research. W.H. Freeman and Co., San Francisco, 859 pp.

Stevenson, J.R., 1985. Dynamics of the integument. In: Bliss, D.E., Mantel, L.H. (Eds.), The Biology of Crustacea, Vol. 9. Academic Press, New York, pp. 1-42.

Theede, H., 1969. Einige neue Aspekte bei der Osmoregulation von Carcinus maenas. Mar. Biol. 2, 114-120.

Williams, A.B., 1984. Shrimps, Lobsters, and Crabs of the Atlantic Coast of the Eastern United States, Maine to Florida. Smithsonian Institution Press, Washington, DC, $550 \mathrm{pp}$.

Wolff, W.J., Sandee, A.J.J., 1971. Distribution and ecology of the Decapoda Reptantia of the estuarine area of the rivers Rhine, Meuse, and Scheldt. Neth. J. Sea Res. 5, 197-226.

Zeidler, W., 1978. Note on the occurrence of the European shore crab Carcinus maenas (Linn., 1758) in Australia. South Australian Naturalist 53, 11-12.

Zeng, C., Naylor, E., 1996. Endogenous tidal rhythms of vertical migration in field collected zoea-1 larvae of the shore crab Carcinus maenas: implications for ebb tide offshore dispersal. Mar. Ecol. Prog. Ser. 132, $71-82$.

Zeng, C., Naylor, E., 1996. Occurrence in coastal waters and endogenous tidal swimming rhythms of late megalopae of the shore crab Carcinus maenas: implications for onshore recruitment. Mar. Ecol. Prog. Ser. 136, 69-79.

Zeng, C., Naylor, E., 1996. Heritability of circatidal vertical migration rhythms in zoea larvae of the crab Carcinus maenas (L.). J. Exp. Mar. Biol. Ecol. 202, 239-257. 